\title{
The effects of paclobutrazol on enhancing tolerance of Plantago major L. to cadmium stress in vitro
}

\author{
Shamil I. Neamah ${ }^{1 *}$, Alla Hussein Hamad $^{2}$ \\ ${ }^{1}$ Center of Desert Studies, University of Anbar, Ramadi, Iraq \\ ${ }^{2}$ Department of Horticulture, College of Agriculture, University of Anbar, Ramadi, Iraq
}

*Corresponding author: ds.dr.shamil@uoanbar.edu.iq

\begin{abstract}
The plant tissue culture technique has enabled us to study the tolerance of cells, tissues, and plant organs and cultures to different stresses that plants suffer from. The in vitro culture facilitates the ability to stimulate the production of secondary metabolites. The present study investigated the influence of paclobutrazol (PBZ) pre-treatment on the growth, physiological, morphological, biochemical traits, and phenolic compounds production in callus cultures of Plantago major L. in a medium containing different concentrations of cadmium. The callus was cultured in a Murashige and Skoog (MS) medium with different concentrations of cadmium (0, 50, 100, 150, and $200 \mu \mathrm{M}$ ), with a PBZ concentration of 0 and $2 \mathrm{mg} \mathrm{l}^{-1}$. A factorial experiment based on a completely randomized design (CRD) was performed in triplicate. The results of the growth of the callus culture were obtained after 28 days. The increasing concentrations of cadmium were found to have a negative effect on some traits such as fresh weight (FW), dry weight (DW), browning intensity (BI), tolerance index (TI), electrolyte leakage (EL), and membrane stability index (MSI). The PBZ treatment reduced the effects of cadmium levels through the decrease in malondialdehyde (MDA), and hydrogen peroxide $\left(\mathrm{H}_{2} \mathrm{O}_{2}\right)$. This was caused by a significant increase in superoxide dismutase (SOD) and ascorbate peroxidase (APX). Also, there was an increase in total phenol and flavonoids content in the callus grown on the tissue cultures supporting $200 \mu \mathrm{M}$ cadmium compared to the other levels. The PBZ pre-treatment was a significant reducing factor to produce total phenolic and flavonoids content in P. major L. callus culture under the cadmium levels.
\end{abstract}

Keywords: Cadmium, callus culture, heavy metals stress, Paclobutrazol, phenolic compounds, Plantago major L. Abbreviations: ROS_reactive oxygen species; H2O2_hydrogen peroxide; OH_hydroxyl; 1O2_singlet oxygen; O2-_superoxide; SOD_superoxide dismutase; POD_peroxidase; GR_glutathione reductase; Apx_ascorbate peroxidase; CAT_catalase; MDAR_monodehydroascorbate reductase; DHAR_dehydroascorbate reductase; MDA_malondialdehyde; PBZ_paclobutrazol; ABA_ abscisic acid; MS_murashige and skoog; 2,4-D_2,4-dichlorophenoxyacetic acid; Kin._ Kinetin; FW_fresh weight; DW_dry weight; TI_tolerance index; EL_electrolyte leakage; MSI_membrane stability index; TCA_tri-chloroacetic acid; TBA_thiobarbituric acid; PVP_polyvinylpyrrolidone; NBT_nitroblue-tetrazolium; AA_ascorbic acid.

\section{Introduction}

Plantago major L. belongs to the family of Plantaginaceae. It is one of the most important medicinal herbs and it has several natural compounds such as polysaccharides, organic acids, lipids, Alkaloids, terpenoids, caffeic acid, flavonoids, and iridoid glycosides (Samuelsen, 2000). Phytochemicals have been derived from this plant, and it has several therapeutic properties including being an antioxidant, antiulcerogenic, analgesic, anti-inflammatory, immunomodulatory, antibiotic, wound healing activity (Samuelsen, 2000), anti-ulcerogenic activity (Abud et al., 2012), antiviral (Chiang et al., 2002), antidiarrheal (Atta and Mouneir, 2005) anticancer (Galvez et al., 2003), and hepatoprotective (Turel et al., 2009).

Heavy metal stress represents an abiotic stress. It is wellknown that they have high solubility in water and high toxicity. Heavy metals stress causes metabolic pathway modifications in the cell, which enhances the production of ROS, such as $\mathrm{H} 2 \mathrm{O} 2, \cdot \mathrm{OH}, 1 \mathrm{O}_{2}$, and $\mathrm{O} 2-$. The ROS reacts with DNA, proteins, and lipids leading to DNA damage, protein denaturation, and lipid peroxidation (Torres-Franklin et al., 2008). Plants have developed their defensive systems (i.e. enzymatic and nonenzymatic) to reduce the harmful effects of ROS. Enzymatic systems include scavenges from $\mathrm{O}_{2-}$ to $\mathrm{H}_{2} \mathrm{O}_{2}$ depending on the SOD, POD, GR, APX, and CAT. On the other hand, POD, CAT, APX, GR, MDAR, and DHAR decompose $\mathrm{H}_{2} \mathrm{O}_{2}$ to $\mathrm{H}_{2} \mathrm{O}$ at several cellular sites (Noctor and Foyer, 1998). The equipoise between antioxidant enzymes activities and ROS production defines if there will be oxidizing or harm signals or not.

Cadmium is a non-essential element of plant growth. It is a non-redox metal that is strongly toxic and causes growth inhibition to plants. Therefore, it causes several harmful effects 
to plant tissues such as reducing biomass, increasing oxidative stress, disruption of biological processes, and causing plant death. One of the mechanisms of the influence of cadmium on the biomass of the plant cell is to disrupt its absorption activity of essential nutrients via its role in replacing ions in the active sites of some enzymes (Jasinski et al., 2008). Cadmium treatments were effective in Brassica juncea callus, which has led to an increase in the tissue content of proline and MDA. This caused an increase in the activity of antioxidant enzymatic system including SOD, APX, and CAT (Shekhawat et al., 2010).

PBZ is one of the plant growth regulators and it belongs to the triazole family. It can inhibit the growth of plant cells based on its role in inhibiting the synthesis of gibberellin, reducing ethylene production, and enhancing the production of $A B A$ and cytokinin contents (Kamountsis et al., 1999). Those changes in the levels of phytohormones has caused several modifications in the physiological and biochemical properties that affect the event responses to the tolerance of abiotic stress (Soumya et al., 2017). PBZ reduces the absorption of $\mathrm{Cu}$ and accumulation in Panicum maximum under exaggerated $\mathrm{Cu}$ stress (Huo et al., 2012). PBZ molecules can probably be used to elicit reactions by specific enzymes in the biosynthesis of secondary metabolite compounds in tissue cultures.

To date, there has been no study dealing with the metabolic modification in the biochemical responses, and secondary metabolites changes of $P$. major callus cultures under heavy metals stress. Also, to the best of our knowledge, the effects of the interaction between PBZ treatment and heavy metals stress have not been investigated on the callus culture, derived from $P$. major. This study aimed to test pre-treatment of PBZ to enhance cadmium tolerance of $P$. major L. callus cultures, and to investigate the growth, morphological, physiological traits, and phenolic compounds produced in the cultures for the first time.

\section{Results and discussion}

\section{Growth, morphological, and physiological traits}

Growth, morphological and physiological changes in the callus cultures of $P$. major $L$. in a medium containing different levels of cadmium, before and pre-treatment by PBZ, are shown in (Figures 1 and 2). FW, DW, and MSI were reduced significantly with increasing cadmium levels. The lowest values were observed for these traits in callus tissue on a media with a 200 $\mu \mathrm{M}$ cadmium level. On the other hand, traits such as $\mathrm{BI}, \mathrm{TI}$, and EL were increased significantly with the continuous increase of cadmium levels. Therefore, the highest $\mathrm{BI}, \mathrm{TI}$, and $\mathrm{EL}$ percentages were observed at $200 \mu \mathrm{M}$ cadmium and PBZ pretreatment (Figures 1 and 2). The cadmium in the culture media had an immediate influence on callus resulting to lower tissue biomass and physiological attributes. Rising the levels of cadmium in the media decreased callus membrane permeability and led to a negative impact on the water balance (Sharma and Pant, 2018). Subsequently, this caused an influence on the stability of the membrane and increased EL in tissue cultures (Belkhadi et al., 2010). This caused cell degradation (i.e. a negative influence on the cells) and led to reducing the tissue callus growth. There was a reduction in FW and DW under cadmium induced heavy metals stress, which was also shown in Brassica juncea callus (Shekhawat et al.,
2010), callus cultures of Gossypium hirsutum L. (Daud et al., 2014), and biomass in Brassica rapa (Navarro-Leon et al., 2019). However, increase in PBZ concentration removed the negative effect of cadmium levels on growth, morphological, and physiological traits. The results showed that treatment of PBZ without cadmium stress promoted FW, DW, BI, HI, EL and MSI traits, compared to the control treatment of both PBZ and cadmium. PBZ acted as a stress safeguard by influencing the levels of the endogenous hormone, and cellular membrane stability, subsequently enhanced the growth traits of biomass (Huo et al., 2012; Soumya et al., 2017).

\section{Biochemical traits}

The effect of environmental stresses on the severity of oxidative stress and the degree of cellular membranes degradation was determined depending on $\mathrm{H}_{2} \mathrm{O}_{2}$ and MDA assays. In this research, the content of $\mathrm{H}_{2} \mathrm{O}_{2}$ and MDA in the callus were increased significantly $(p<0.05)$ with the continuous increase in cadmium levels. The highest content of $\mathrm{H}_{2} \mathrm{O}_{2}$ and MDA were shown at the level of $200 \mu \mathrm{M}$ cadmium by 11.07 and $744.7 \mu \mathrm{mol} \mathrm{g}{ }^{-1}$ of $\mathrm{FW}$. The PBZ pretreatment resulted in a lower content of $\mathrm{H}_{2} \mathrm{O}_{2}$ and MDA by all levels of cadmium. The levels of $\mathrm{H}_{2} \mathrm{O}_{2}$ and MDA content were not significant in the PBZ pretreated callus tissues in the cadmiumfree media. In the absence of PBZ and cadmium, the levels of $\mathrm{H}_{2} \mathrm{O}_{2}$ and MDA were 4.90 and $4.83 \mu \mathrm{mol} . \mathrm{g}^{-1} \mathrm{FW}$ and 243.3 and $220.7 \mu \mathrm{mol} . \mathrm{g}-1 \mathrm{FW}$, respectively.

Elicitors and several stresses, including heavy metal stress, caused an increase in the level of free radicals and ROS creating oxidative stress, which caused damage to the cell's membrane. The quantity of this damage depended on the severity of oxidative stress and ROS such as $\mathrm{H}_{2} \mathrm{O}_{2}$ (Mohamed et al., 2012).

In this study, cultures treated with heavy metals stress under cadmium levels caused $\mathrm{H}_{2} \mathrm{O}_{2}$ accumulation, which resulted in higher MDA content and degradation of the cell membrane (Figure $3 \mathrm{~A}$ and $\mathrm{B}$ ).

These results showed the possibility of PBZ concentrations, as it was effective in reducing the content of callus cultures from free radicals by reducing $\mathrm{H}_{2} \mathrm{O}_{2}$ and MDA. This was consistent with the results of the study on physiological traits (Figure 3 ), indicating the possibility of using PBZ in protecting cell membranes from oxidative stress. Also, similar findings were observed by (Upadhyaya et al., 1985; Manivannan et al., 2008; Hajihashemi and Ehsanpour, 2014; Xiu et al., 2018; Waqas et al., 2018).

There are many mechanisms for plant cells to tolerate abiotic stresses, including the prevention of oxidative damage that causes an increase in the antioxidant activity (Ahmad et al. 2008; Gill and Tuteja 2010; Karuppanapandian et al., 2011). The antioxidant enzymes activity of $P$. major $L$. callus cultures pretreated by PBZ and cadmium levels is shown in Figure 4.

The SOD activity increased by multiplying the content of cadmium levels in the media of cultures. It was significantly ( $p$ $<0.05$ ) higher (60.03 u. $\mathrm{mg}^{-1}$ protein) in cadmium concentration of $200 \mu \mathrm{M}$. PBZ concentrations enhanced SOD activity. There was a significant $(p<0.05)$ effect in the SOD activity of callus grown with 100,150 , and $200 \mu \mathrm{M}$ cadmium, reaching 47.00, 60.03 , and $56.06 \mathrm{u.} \mathrm{mg}^{-1}$ protein, respectively. 


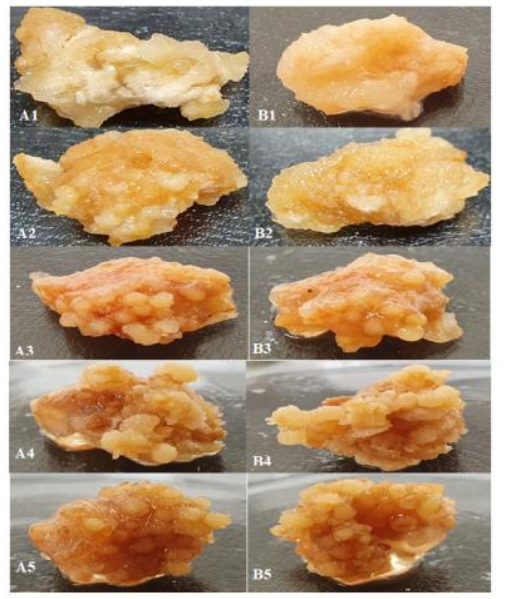

Fig 1. Changes of $P$. major L. tissue callus on media containing cadmium levels (A) $0,50,100,150$, and $200 \mu \mathrm{M}$, respectively. (B) The same levels after PBZ treated by $2.0 \mathrm{mg} / \mathrm{l}$ concentration.
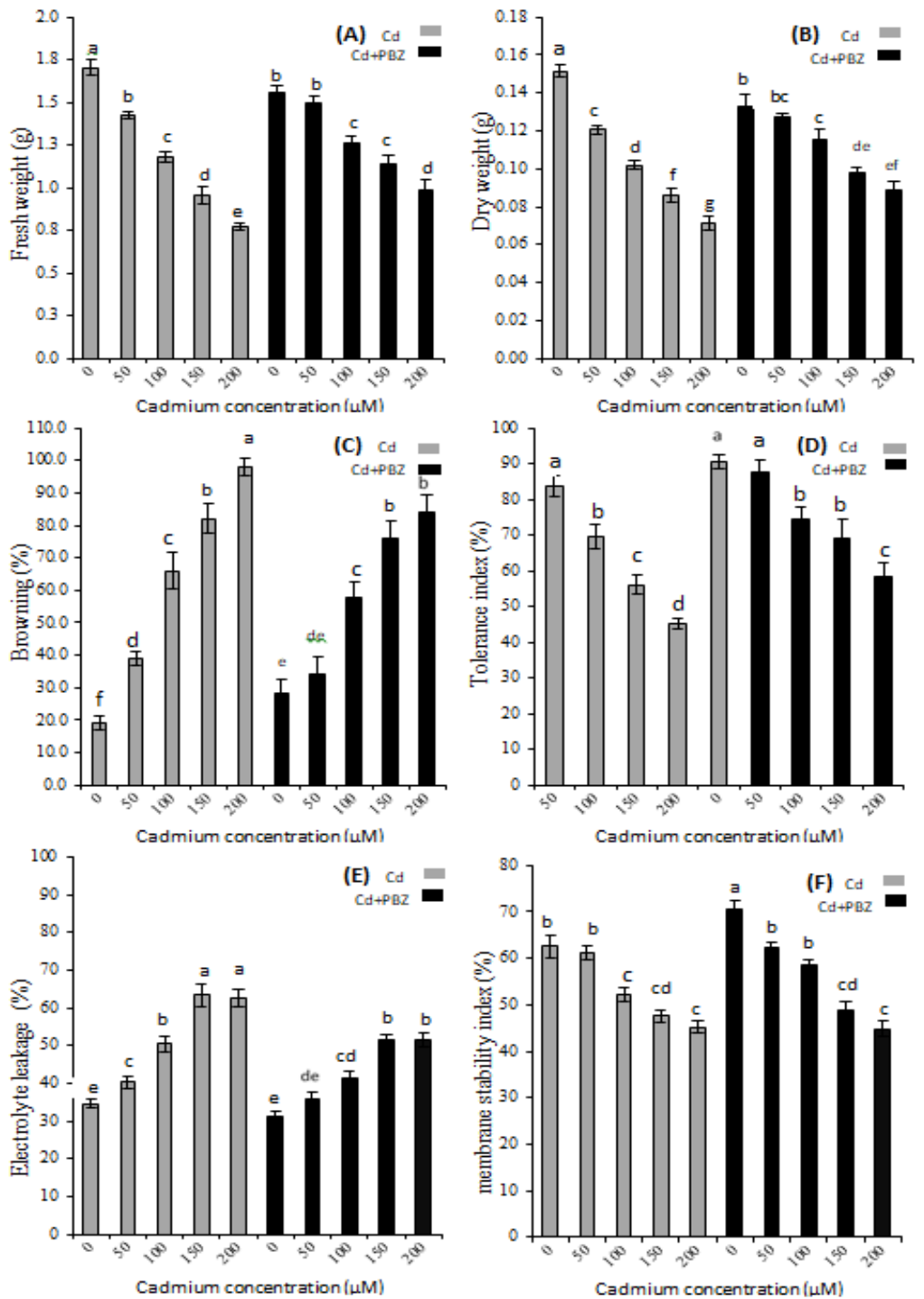

Fig 2. (A) FW, (B) DW, (C) BI, (D) TI, (E) EL, (F) MSI, exposed to different levels of cadmium and PBZ pretreatment in callus culture of $P$. major L. for 28 days. 

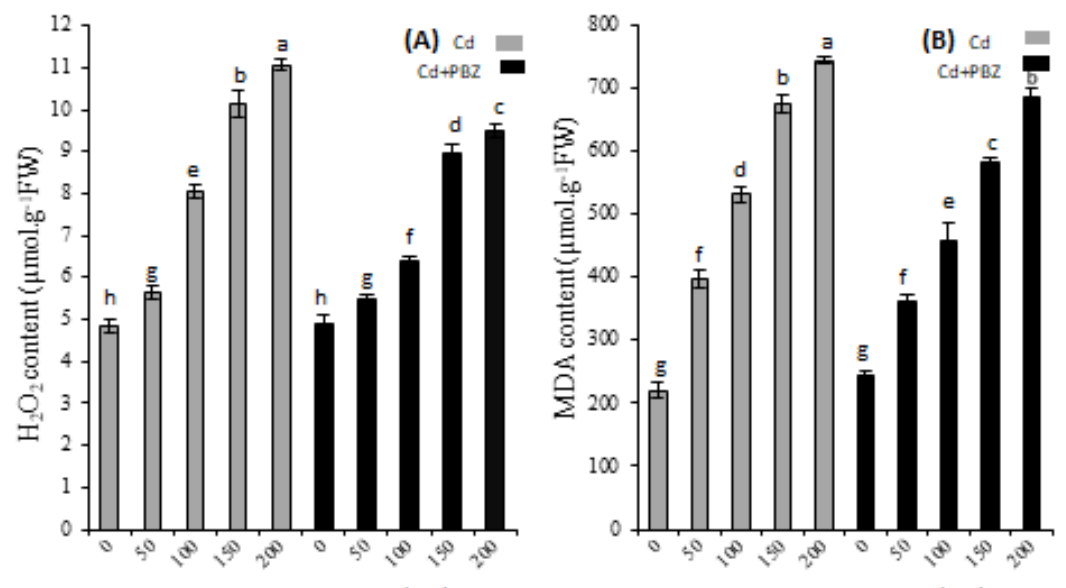

Cadmium concentration (uM)

Cadmium concentration ( $\mu$ M)

Fig 3. (A) $\mathrm{H}_{2} \mathrm{O}_{2}$ content, (B) MDA content, exposed to different levels of cadmium and PBZ pretreatment in callus culture of $P$. major $L$. for 28 days.
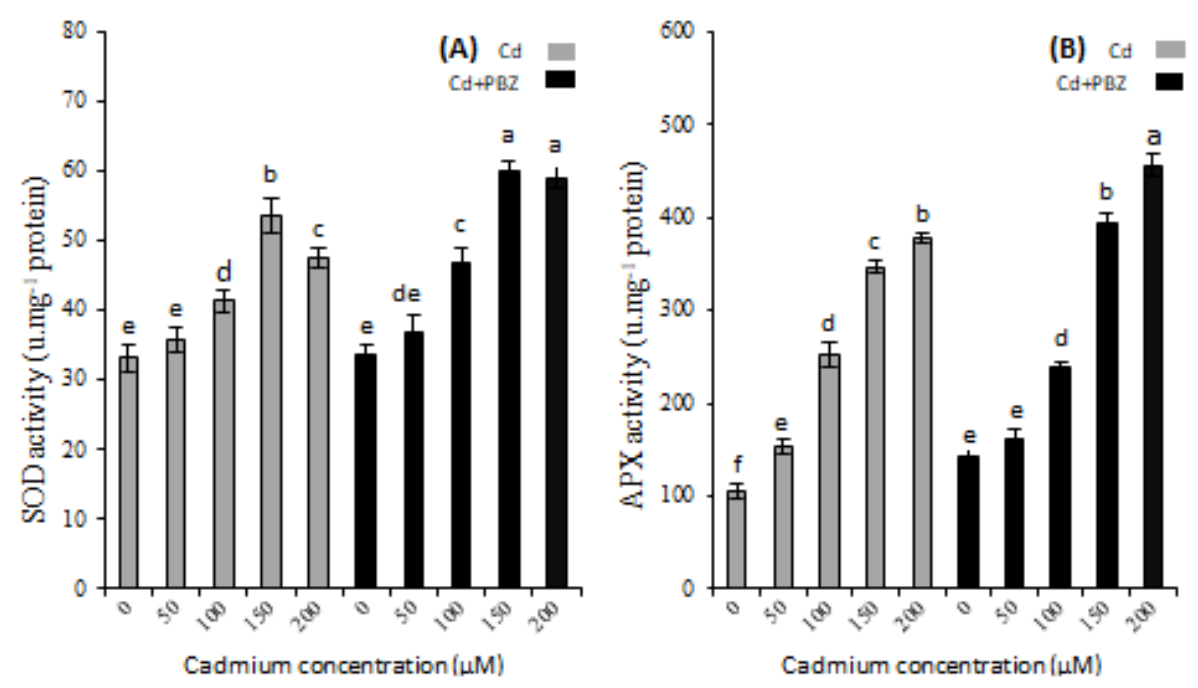

Fig 4. (A) SOD activity, (B) APX activity, exposed to different levels of cadmium and PBZ pretreatment in callus culture of Plantago major L. for 28 days.
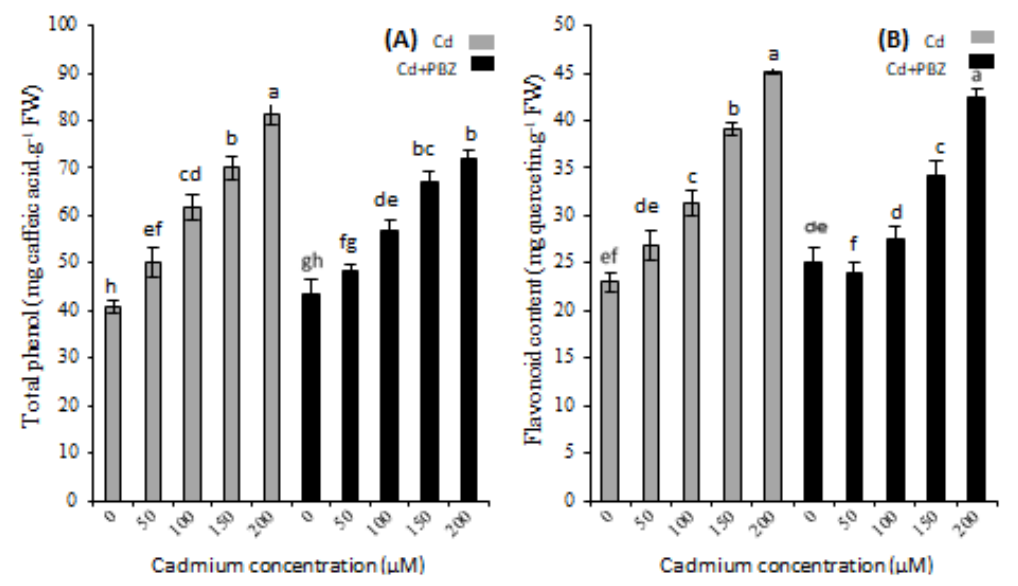

Fig 5. (A) total phenol, (B) flavonoid content, exposed to different levels of cadmium and PBZ pretreatment in callus culture of $P$. major L. for 28 days. 
Then non-treated and pretreated culture by $25 \mu \mathrm{M}$ PBZ concentrations showed non-significant difference (Figure 4A) APX activity was promoted by higher cadmium levels, with a significant $(p<0.05)$ difference when it was observed with the continuous increase in cadmium levels. The highest value recorded was $200 \mu \mathrm{M}$ reaching 378.00 u.mg-1 protein. The pre-treatment with PBZ was significantly $(p<0.05)$ different in APX activity in cadmium levels samples compared to the nontreated samples. We found a significant $(p<0.05)$ difference between PBZ pre-treated callus cultured with 150 or $200 \mu \mathrm{M}$ cadmium, they had 393.33 and 457.00 u.mg-1 protein, respectively (Figure $4 \mathrm{~B}$ ).

The activities of SOD and APX were increased by raising the cadmium level to $200 \mu \mathrm{M}$, as shown in Figure 4, and was significantly promoted by PBZ at various cadmium concentrations. SOD and APX activities pre-treated by PBZ callus and enhanced by $150 \mu \mathrm{M}$ cadmium were $77.45 \%$ and $174 \%$ higher, respectively, compared to the sample containing PBZ without cadmium. The enzymatic antioxidants are an important mechanism for eliminating the risk of free radicals and their negative effects on plant cells. Antioxidant enzymes are important in protecting the plant from the impact of various environmental stresses, and their activity depends on the plant type, type of stress and the duration of stress. SOD is the most important enzyme used to remove free radicals in plant cells, so it leads to a vital role in cell defense mechanisms against the risk of hydroxyl radical $(\mathrm{OH})$. It was formed by converting the radical superoxide (O2-) to $\mathrm{H} 2 \mathrm{O} 2$ in chloroplasts, cytosol, and mitochondria (Alscher et al., 2002; Souri et al., 2017). The activity of antioxidant enzymes depends on stress severity. Antioxidant enzymes can avoid the risk of lower or moderate levels of metals stress. Free radicals increase their production in the cell under high-stress conditions, making it difficult to remove at the same speed, which leads to cell degradation by destroying antioxidant enzymes and proteins.

The reduction of SOD activity observed at $200 \mu \mathrm{M}$ cadmium may be consequent to the impaired resistance of $P$. major $L$. callus culture with increasing levels from the stress of the oxidative. The increased activity of APX under $200 \mu \mathrm{M}$ of cadmium concentration was recompensed by the lower activity of the SOD enzyme. The SOD and APX activities were similar to the results of previous researchers under conditions of environmental stress (Upadhyaya et al., 1985; Manivannan et al., 2008; Hajihashemi and Ehsanpour, 2014; Xiu et al., 2018; Waqas et al., 2018). Furthermore, a similar article indicated the role of PBZ concentrations in increasing the activity SOD in Vigna unguiculata under salt stress (Manivannan et al., 2008) and APX in Stevia rebaudiana under drought stress (Hajihashemi and Ehsanpor, 2014).

\section{Phenolic compounds}

The total phenolic and flavonoid content in P. major L. callus was increased notably with the metals stress stimulated by a higher cadmium levels in the culture media (Figure 5). The levels of total phenol and flavonoid content were increased with the higher levels of cadmium treatment, when treated by $200 \mu \mathrm{M}$ of cadmium. Both groups showed increased of $99.51 \%$ and $96.39 \%$, respectively, compared to the control sample.
The pre-treatment by PBZ affected the content in callus cultures from total phenols and flavonoids. This caused a significant decrease in several products from those secondary compounds, compared to the results of cadmium induction coefficients. The pre-treatment with PBZ improved the content of callus cultures from flavonoids, compared to the control treatment by cadmium only (Figure $5 \mathrm{~B}$ ).

The process of stimulating the pathways for the synthesis of secondary compounds such as phenolic compounds is among the important defense systems to reduce the risk effects of oxidative stress (Oh et al., 2009; Sarmadi et al., 2018).

The levels of cadmium stress strongly influenced on the production of phenolic compounds. We found a similar result in several articles (Marquez-Garcia et al., 2012; Ibrahim et al., 2017; Colak et al., 2019).

PBZ pre-treatment systematically increased the activity of antioxidant enzymes, including SOD and APX. This caused a reduction in levels of phenol production. The PBZ contributed to the grabbing of free radicals and reduced the impact of oxidative stress. Our results were consistent with Hajihashemi and Ehsanpour, (2014) and Lucho et al., (2018). Consequently, the $\mathrm{BI}$ of $P$. major L. callus was lower in the PBZ pre-treated callus in cadmium-containing media. The increased tolerance of tissue to cadmium led to the enhancement of traits of growth (Figure 2).

\section{Materials and methods}

\section{Seeds germination and callus induction}

This experiment was carried out in plant tissue culture laboratory, Center of Desert Studies, University of Anbar (33 $24^{\prime} 11^{\prime \prime} N, 43^{\circ} 15^{\prime} 43^{\prime \prime} E$ ). The seeds of $P$. major L. were washed with tap water for 30 minutes, sterilized with $2.0 \%$ sodium hypochlorite for ten minutes to obtain sterile seedlings, and then were rinsed with sterile water three times. The cotyledon was used for explant to obtain the callus indication and, it was cut into pieces of $1.0 \mathrm{~cm}$ in length, cultured on MS media (Murashige and Skoog, 1962), supplemented with $2.0 \mathrm{mg} / \mathrm{l} \mathrm{2,4-}$ D, $0.4 \mathrm{mg} / \mathrm{l} \mathrm{Kin,} 30.0 \mathrm{~g} / \mathrm{l}$ sucrose and $8.0 \mathrm{~g} / \mathrm{l}$ agar. The cultures were incubated in darkness at $25 \pm 1{ }^{\circ} \mathrm{C}$ for 28 days for callus induction.

\section{Callus culture initiation and treatment}

P. major L. callus culture was obtained after several subcultures on MS medium containing $3.0 \mathrm{mg} / \mathrm{l}$ 2,4-D, $1.0 \mathrm{mg} / \mathrm{l}$ Kin., $30.0 \mathrm{~g} / \mathrm{l}$ sucrose, and $8.0 \mathrm{~g} / \mathrm{l}$ agar as a callus reproduction medium, and incubated in darkness at $25 \pm 1{ }^{\circ} \mathrm{C}$ (Neamah, 2020). The growing callus was cultured in two groups of experimental treatments. The first group was treated by cadmium concentrations $(0,50,100,150$, and $200 \mu \mathrm{M})$. CdSO4.H2O was used as a source. The second group was pre-treated with 2.0 $\mathrm{mg} / \mathrm{l}$ of PBZ for $72 \mathrm{~h}$. Thereafter, they were sub-cultured on the media supplemented with the same cadmium levels. The callus culture was analyzed after 28 days.

\section{Growth and physiological traits of callus culture}


The callus was pulled from tissue cultures, cleaned from the remains of media and weighed to measure the FW. It was dried in an oven at 40 으 for $72 \mathrm{~h}$, and the DW was measured. The browning intensity of the treated callus was determined after 28 days of callus tissue growth by classifying it into five main groups from lowest to highest. Callus TI was determined based on a previously provided description (Shekhawat et al., 2010). The EL and MSI was determined as previously described by Hnilickova et al., (2019) and Chandrasekar et al., (2000), respectively.

\section{$\mathrm{H}_{2} \mathrm{O}_{2}$ Content}

The spectrophotometric method was used to determine the content of $\mathrm{H}_{2} \mathrm{O}_{2}$ from callus samples according to Alexieva et al., (2001). A $0.1 \%$ TCA was added to $500 \mathrm{mg}$ of fresh callus. The absorbance of the supernatant was determined at $390 \mathrm{~nm}$. Using the $\mathrm{H}_{2} \mathrm{O}_{2}$ standard curve, the $\mathrm{H}_{2} \mathrm{O}_{2}$ concentration was calculated.

\section{Lipid peroxidation assay}

The assay was conducted to measure the amount of MDA production based on the method provided by Heath and Packer (1968). Three hundred milligrams of fresh callus was symmetric in a $1 \%$ TCA solution. The MDA quantity was measured by deducting the absorbance at 532 and $600 \mathrm{~nm}$ using $155 \mathrm{mM}-1 \mathrm{~cm}-1$ as an extinction coefficient.

\section{Determination of antioxidant enzyme activity}

Antioxidant enzymes were extracted using $500 \mathrm{mg}$ of fresh callus which was symmetrized in a potassium phosphate buffer (50 mM, pH 7), including EDTA (1mM) and 1\% PVP. It was determined using the supernatant factions according to the method provided (Gapinska et al., 2008).

SOD activity was measured based on the method described by Giannopolitis and Ries (1977). The absorption was recorded at $560 \mathrm{~nm}$. The activity enzyme SOD was determined by considering that one unit of it represents the amount of the enzyme that inhibits $50 \%$ of the NBT photoreduction.

The activity of APX was measured as described by Nakano and Asada (1981). The reaction mixture contained of $0.15 \mathrm{mM} \mathrm{H}_{2} \mathrm{O}_{2}$, $0.1 \mathrm{Mm}, 0.5 \mathrm{Mm} \mathrm{AA}$, and $50 \mathrm{mM}$ potassium phosphate buffer (pH 7.0). $1000 \mu \mathrm{l}$ of this mixture was added to $150 \mu \mathrm{l}$ of enzyme extract. The decrease in absorbance at $290 \mathrm{~nm}$ was due to the consumption of $\mathrm{H}_{2} \mathrm{O}_{2}$ (extinction co-efficient 2.8 $\mathrm{mM}^{-1} \mathrm{~cm}^{-1}$ ).

\section{Phenolic compounds}

The quantity of phenolic content in callus tissue was determined based on the modified method of Folin and Ciocalteu's reagent (Singleton and Rossi, 1965). In $100 \mathrm{mg}$ of samples, $95 \%$ ethanol was the extraction solvent. The medley of absorption was recorded at $490 \mathrm{~nm}$ using caffeic acid as standard curve.

The total quantity of flavonoids was determined based on the modified method of Ordonez et al. (2006). The flavonoids were extracted from $100 \mathrm{mg}$ of fresh callus in a mixture of chloroform and methanol $(1: 1, \mathrm{v} / \mathrm{v})$. The resulting medley at the final stage was recorded at $420 \mathrm{~nm}$ absorbance using quercetin in the standard curve.

\section{Statistical analysis}

The experimental factorial was designed by using a complete randomized design in three replications. Variation analysis (ANOVA) was performed for the data using Genstat software version 19. Tukey's test was used to determine the differences between mean values for different treatments at $p<0.05^{*}$.

\section{Conclusion}

For the first time in this work, the influence of cadmium and PBZ pre-treatment on P. major L. tissue cultures was studied. The stimulation process contributed to oxidative stress and raised the levels of free radicals including $\mathrm{H}_{2} \mathrm{O}_{2}$ and MDA. The cadmium treatment decreased the membrane stability and increased cell degradation and callus death. To protect the cell from the impact of heavy metal stress, the activity of the antioxidant enzymatic system was increased. The total content of phenolic compounds was also increased. The PBZ pretreated callus cultures showed a boost to the growth of callus cultures by increasing the anti-oxidant enzymatic activity that contributed to the capture of free radicals; thus improved the tissue's tolerance to cadmium stress. The PBZ pre-treated callus cultures showed a boost to the growth of callus cultures (FW and DW) by increasing the anti-oxidant enzymatic activity that contributed to scavenging free radicals; thus improved the tissue's tolerance to cadmium stress (TI). However, the increase of concentrations of PBZ caused inhibition of phenolic compounds in the callus culture.

\section{Acknowledgments}

We wish to thank the University of Anbar for providing the necessary requirements for this work. We also acknowledge Dr. Ahmed F. Muslah for assisting us in carrying out statistical analyses. Dr. Ahmed Sh. Lafi improved the manuscript and Mr. Mohammed Rasheed helped in the discussion.

\section{References}

Abud MA, Molina A, Wendel G, Hikawczuk VEJ, Pelzer L, Maria AO, Saad JRC (2012) Gastroprotective effect of Plantago major and metabolites in Rats. Lat Am J Pharm. 31(8): 12031206.

Ahmad P, Serwat M, Sharma S (2008) Reactive oxygen species, antioxidants and signaling in plants. J Plant Physiol. 51(3):167-173.

Alexieva V, Sergiev I, Mapelli S, Karanov E (2001) The effect of drought and ultraviolet radiation on growth and stress markers in pea and wheat. Plant Cell Environ. 24:1337-1344.

Alscher RG, Erturk N, Heath LS (2002) Role of superoxide dismutases (SODs) in controlling oxidative stress in plants. J Exp Bot. 53:1331-1341.

Atta H, Mouneir SM (2005) Evaluation of some medicinal plant extracts for antidiarrheal activity. Phytother Res. 19(6): 481485. 
Belkhadi A, Hediji H, Abbes Z, Nouairi I, Barhoumi Z., Zarrouk Z, Chaibi W, Djebali W (2010) Effects of exogenous salicylic acid pre-treatment on cadmium toxicity and leaf lipid content in Linum usitatissimum L. Ecotox Environ Safe. 73:1004-1011.

Chandrasekar V, Sairam RK, Srivastava GC (2000) Physiological and biochemical responses of hexaploid and tetraploid wheat to drought stress. J Agron Crop Sci. 185(4): 219-227.

Chiang LC, Chiang W, Chang MY, Ng LT, Lin CC (2002) Antiviral activity of Plantago major extracts and related compounds in vitro. Antivir Res. 55(1):53-62.

Colak N, Torun H, Gruz J, Strnad M, Ayaz FA (2019) Exogenous $\mathrm{N}$-Acetylcysteine alleviates heavy metal stress by promoting phenolic acids to support antioxidant defence systems in wheat roots. Ecotox Environ Safe. 181:49-59.

Daud MK, Mei L, Najeeb U, Khan MA, Deeba F, Raza I, Batool A, Zhu SJ (2014) In Vitro Cadmium-Induced Alterations in Growth and Oxidative Metabolites of Upland Cotton (Gossypium hirsutum L.). Sci World J. page 10.

Galvez M, Martin-Cordero C, Lopez-Lazaro M, Cortes F, Ayuso MJ (2003) Cytotoxic effect of Plantago Spp. on cancer cell lines. J Ethnopharmacol. 88:125-130.

Gapinska M, Skłodowska M, Gabara B (2008) Effect of short and long-term salinity on the activities of antioxidative enzymes and lipid peroxidation in tomato roots. Acta Physiol Plant. 30(1):11-18.

Giannopolitis CN, Ries SK (1977) Superoxide dismutases I. Occurrence in higher plants. Plant Physiol. 59(2):309-314.

Gill SS, Tuteja N (2010) Reactive oxygen species and antioxidant machinery in abiotic stress tolerance in crop plants. Plant Physiol Bioch. 48:909-930.

Hajihashemi S, Ehsanpour AA (2014) Antioxidant response of Stevia rebaudiana B. to polyethylene glycol and paclobutrazol treatments under in vitro culture. Appl Biochem Biotech. 172:4038-4052.

Heath RL, Packer L (1968) Photoperoxidation in isolated chloroplasts: I. Kinetics and stoichiometry of fatty acid peroxidation. Arch Biochem Biophys. 125:189-198.

Hnilickova H, Hnilicka F, Orsak M, Hejnak V (2019) Effect of salt stress on growth, electrolyte leakage, $\mathrm{Na}+$ and $\mathrm{K}+$ content in selected plant species. Plant Soil Environ. 65(2):90-96.

Huo W, Zhuang C, Cao Y, Pu M, Yao H, Lou L, Cai Q (2012) Paclobutrazol and plant-growth promoting bacterial endophyte Pantoea sp. enhance copper tolerance of guinea grass (Panicum maximum) in hydroponic culture. Acta Physiol Plant. 34:139-150.

Ibrahim MH, Kong YC, Zain NAM (2017) Effect of Cadmium and Copper Exposure on Growth, Secondary Metabolites and Antioxidant Activity in the Medicinal Plant Sambung Nyawa Gynura procumbens (Lour.) Merr. Molecules. 22:1623(1-16).

Jasinski M, Sudre D, Schansker G, Schellenberg M, Constant S, Martinoia E, Bovet L (2008) Atosa1, a member of the abc1like family, as a new factor in cadmium and oxidative stress response. Plant Pathol. 147(2):719-731.

Karuppanapandian T, Moon JH, Kim C, Manoharan K, Kim W (2011) Reactive oxygen species in plants: their generation, signal transduction, and scavenging mechanisms. Aust J Crop Sci. 5(6):709-725.

Kamountsis AP, Chronopoulou-Sereli AG, Paspatis EA (1999) Paclobutrazol affects growth and flower bud production in gardenia under different light regimes. Hortic Sci. 34(4):674675.

Lucho SR, Amaral MN, Lopez-Orenes A, Kleinowsk AMi, Amarante L, Ferrer MA, Calderon AA, Braga EJB (2018). Plant Growth Regulators as Potential Elicitors to Increase the contents of Phenolic Compounds and Antioxidant Capacity in Stevia Plants. Sugar Tech. 21:696-702.

Marquez-Garcia B, Fernandez-Recamales MA, Cordoba F (2012) Effects of Cadmium on Phenolic Composition and Antioxidant Activities of Erica andevalensis. J Bot. 936950:16.

Manivannan P, Jaleel CA, Kishorekumar A, Sankar B, Somasundaram R, Panneerselvam R (2008) Protection of Vigna unguiculata (L.) Walp. plants from salt stress by paclobutrazol. Colloid Surface B. 61(2):315-3188.

Mohamed AA, Castagna A, Ranieri A, Sanita di Toppi L (2012) Cadmium tolerance in Brassica juncea roots and shoots is a_ected by antioxidant status and phytochelatin biosynthesis. Plant Physiol Bioch. 57:15-22.

Murashige T, Skoog F (1962) A revised medium for rapid growth and bioassays with tobacco cultures. Physiol Plantarum. 15:473-497.

Nakano Y, Asada K (1981) Hydrogen peroxide is scavenged by ascorbate-specific peroxidase in spinach chloroplasts. Plant Cell Physiol. 22(5):867-880.

Navarro-Leon E, Oviedo-Silva J, Ruiz JM, Blasco B (2019) Possible role of HMA4a TILLING mutants of Brassica rapa in cadmium. Ecotox Environ Safe. 180:88-94.

Neamah SI (2020) Inducing some secondary metabolites from callus cultures derived from Plantago psyllium and Plantago major exposed to cobalt stress. Iraqi J Agri Sci. 51(3): 938-943.

Noctor G, Foyer CH (1998) Ascorbate and glutathione: keeping active oxygen under control. Annu Rev Plant Biol. 49:249-279.

Oh MM, Trick HN, Rajashekar C (2009) Secondary metabolism and antioxidants are involved in environmental adaptation and stress tolerance in lettuce. J Plant Physiol. 166:180-191.

Ordonez AAL, Gomez JD, Vattuone MA, Isla MI (2006) Antioxidant activities of Sechium edule (Jacq.) Swart extracts. Food Chem. 97:452-8.

Sarmadi M, Naser K, Javier P, Alireza G, Mohammad HM (2018) The effects of salicylic acid and glucose on biochemical traits and taxane production in a Taxus baccata callus culture. Plant Physiol Bioch. 132: 271-280.

Samuelsen AB (2000) The traditional uses, chemical constituents and biological activities of Plantago major L. A review. J Ethnopharmacol. 71(1-2):1-21.

Sharma V, Pant D (2018) Structural basis for expanding the application of bioligand in metal bioremediation: A review. Bioresource Technol. 252:188-197.

Shekhawat GS, Verma K, Jana S, Singh K, Teotia P, Prasad A (2010) In vitro biochemical evaluation of cadmium tolerance mechanism in callus and seedlings of Brassica juncea. Protoplasma. 239(1-4):31-38.

Singleton VL, Rossi JR (1965) Colorimetry of total phenolics with hosphomolybdic-phosphotungstic acid reagent. Am J Enol Viticult. 16:144-158.

Soumya PR, Kumar P, Pal M (2017) Paclobutrazol: a novel plant growth regulator and multi-stress ameliorant. Indian J Plant Physi. 22(3):267-278.

Souri Z, Karimi N, de Oliveira LM (2017) Antioxidant enzymes responses in shoots of arsenic hyperaccumulator, Isatis 
cappadocica Desy, under interaction of arsenate and phosphate. Environ Technol. 39:1316-1327.

Torres-Franklin ML, Contour-Ansel D, Zuily-Fodil Y, Pham-Thi AT (2008) Molecular cloning of glutathione reductase cDNAs and analysis of GR gene expression in cowpea and common bean leaves during recovery from moderate drought stress. J Plant Physiol. 165(5):514-521.

Turel I, Ozbek H, Erten R, Oner AC, Cengiz N, Yilmaz O (2009) Hepatoprotective and anti-inflammatory activities of Plantago major L. Indian J Pharmacol. 41(3):120-124.

Upadhyaya A, Sankhla D, Davis TD, Sankhla N, Smith BM (1985) Effect of paclobutrazol on the activities of some enzyme of activated oxygen metabolism and lipid peroxidation in senescing soybean leaves. J Plant Physiol. 121(5): 453-461.

Waqas M, Yaning C, Iqbal H, Shareef M, Rehman H, Iqbal S, Mahmod S (2018) Soil drenching of paclobutrazol: an efficient way to improvequinoa performance under salinity. Physiol Plantarum. 165(2):219-231.

Xiu WY, Zhu Y, Chen B, Hu Y, Dawuda MM (2018) Effects of paclobutrazol on the physiological characteristics of Malus halliana Koehne seedlings under drought stress via principal component analysis and membership function analysis. Arid Land Res Manag. 33(4):1-17. 